\title{
OCCUPATION STRATEGY OF THE ARBOREAL SPECIES Tachigali rubiginosa (MART. EX TUL.) OLIVEIRA-FILHO: EVIDENCE OF FOREST EXPANSION OVER GRASSLAND AREAS.
}

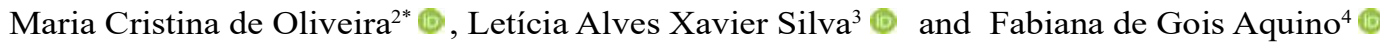

\author{
${ }^{1}$ Received on 31.08.2020 accepted for publication on 13.05.2021. \\ ${ }^{2}$ Universidade de Brasília, Faculdade UnB Planaltina, Planaltina, DF - Brasil. E-mail: <mcrisoliveira@unb.br>. \\ ${ }^{3}$ Universidade de Brasília, Graduanda em Ciências Naturais, Planaltina, DF - Brasil. E-mail: <leticiaemailparticular@gmail.com>. \\ ${ }^{4}$ Empresa Brasileira de Pesquisa Agropecuária, Brasília, DF - Brasil. E-mail: <fabiana.aquino@embrapa.br>. \\ *Corresponding author.
}

\begin{abstract}
Understanding the dynamics of forest species occupation in savanna and grasslands environments allows us to assess how forest expansion operates over time. For eleven years, the population dynamics of Tachigali rubiginosa (Mart. ex. Tul.) Oliveira-Filho was registered to evaluate the occupation strategy of this species in the ecotone between forest (Mata de Galeria) and grassland (Campo Sujo), located within the Capetinga stream basin, at Fazenda Água Limpa, Federal District. This area has been protected from wildfires since 1987. This study allocated thirty-one transects of $5 \mathrm{~m}$ x $100 \mathrm{~m}$ perpendicularly to the Capetinga stream, covering forest and grassland environments. The measurements were taken from adult trees (DBH $\geq$ $5 \mathrm{~cm}$ ), young trees (height $>1 \mathrm{~m}$ and DBH $<5 \mathrm{~cm}$ ) and seedlings (height $\leq 1 \mathrm{~m}$ and DBH $<5 \mathrm{~cm}$ ). The results indicated that, in the studied period, the population of T. rubiginosa increased from 179.5 to 262.8 ind / ha. In 2007 , of the total of 280 individuals in $1.56 \mathrm{ha}, 96$ of them were in the forest $(0.22 \mathrm{ha}), 103$ in the ecotone ( $0.16 \mathrm{ha})$, and 81 in the grassland ( $1.18 \mathrm{ha})$. In 2018, this proportion changed when the number of individuals decreased in the forest ( 83 individuals), while the number increased in the ecotone (135 individuals) and in the grassland (194 individuals). In 2007, the young trees dominated with $71 \%$ of the total, followed by the adults trees (28.5\%) and the seedlings (20.7\%). In 2018, the young trees represented most individuals (39.2\%), but there was a balance between the three size categories, as the seedlings represented $30.0 \%$ and adults trees $30.7 \%$. Over the period of the study, there was an increase in the population of T. rubiginosa, especially of young individuals, which indicates persistence over time and an expansion of this forest species into grassland environments.
\end{abstract}

Keywords: Population dynamics; Fire; Transition areas.

\section{ESTRATÉGIA DE OCUPAÇÃO DA ESPÉCIE ARBÓREA Tachigali rubiginosa (MART. EX TUL.) OLIVEIRA-FILHO: EVIDÊNCIAS DE EXPANSÃO FLORESTAL SOBRE AREAS DE CAMPO SUJO.}

\begin{abstract}
RESUMO - Compreender a dinâmica de ocupação de espécies florestais em ambientes savânicos e campestres permite elucidar como a expansão florestal opera ao longo do tempo. Durante onze anos, foi acompanhada a dinâmica da população da espécie arbórea Tachigali rubiginosa (Mart. ex. Tul.) Oliveira-Filho com objetivo de avaliar a estratégia de ocupação desta espécie no ecótono entre Mata de Galeria e Campo Sujo, na bacia do córrego Capetinga, na Fazenda Água Limpa, Distrito Federal. Esta área encontra-se protegida do fogo desde 1987. Foram alocados 31 transectos de $5 \mathrm{~m} \times 100 \mathrm{~m}$, perpendicularmente ao córrego, cobrindo uma faixa de vegetação que inclui parte da Mata de Galeria e do Campo Sujo. Foram tomadas medidas dos adultos (DAP $\geq$ $5 \mathrm{~cm}$ ), arvoretas (altura $>1 \mathrm{~m}$ e DAP $<5 \mathrm{~cm}$ ) e mudas (altura $\leq 1 \mathrm{~m}$ e DAP $<5 \mathrm{~cm}$ ). Os resultados indicaram que, no período estudado, a população de T. rubiginosa passou de 179,5 para 262,8 ind/ha. Em 2007, do total de 280 indivíduos em 1,56 ha, 96 deles estavam na Mata de Galeria (0,22 ha), 103 no ecótono (0,16 ha) e 81 no Campo Sujo (1,18 ha). Em 2018, o número de indivíduos diminuiu na Mata de Galeria (83 indivíduos),
\end{abstract}




\begin{abstract}
aumentou no ecótono (135 indivíduos) e no Campo Sujo (194 indivíduos). Em 2007, as arvoretas dominavam com $71 \%$ dos indivíduos, seguida dos adultos (28,5\%) e das mudas (20,7\%). Em 2018, apesar das arvoretas ainda representarem a maior parte dos indivíduos (39,2\%), houve certo equilibrio entre as três categorias de tamanho com mudas $(30,0 \%)$ e adultos (30,7\%). Observou-se crescimento da população de T. rubiginosa, sobretudo de indivíduos jovens, o que indica persistência, ao longo do tempo, e expansão desta espécie em direção ao Campo Sujo.
\end{abstract}

Palavras-Chave: Dinâmica populacional; Fogo; Áreas de transição.

\section{INTRODUCTION}

Changes in the populations of plant communities occur over time due to the joint action of limiting factors that affect their density, spatial distribution, mortality, and recruitment, such as space limitations, competition, and climatic conditions, in addition to other factors. The variation in population density depends on the magnitude of fluctuation in the environment, the inherent stability of the population, and the ecological characteristics of the species (Ricklefs and Schluter, 1993). Fluctuations in natural populations are practically unpredictable since individuals are affected by external factors (soil $\mathrm{pH}$, temperature), which are correlated with the characteristics of a given ecosystem (Peroni and Hernández, 2011).

The Cerrado biome has great biotic and abiotic spatial and temporal heterogeneity. These characteristics provide different environmental conditions that native species require in order to utilize available environmental resources and to minimize limiting factors (Ribeiro and Walter, 2008). There are mosaics of different forests, savannas, and grassland environments (Ribeiro and Walter, 2008). Among the physiognomies that make up the different formations mentioned, Mata de Galeria and Campo Sujo represent quite distinct physiognomies when considering the tree density and the depth of the water table as examples (Felfili et al., 1998; Ribeiro and Walter, 2008).

The Mata de Galeria occurs in strips along narrow watercourses in the Cerrado region. Water availability, air temperature, soil characteristics and, above all, light are among the essential factors that influence the development of these physiognomies since they have direct effects on photosynthetic rates (Kozlowski et al., 1991). Under this type of vegetation, the Cambisols, Plintosols, Argisols, or Neossols have greater fertility in comparison to surrounding areas.
These soil types generally occur due to the transport of nutrients from the higher parts of the soil and the presence of organic matter from the vegetation itself (Reatto et al., 2001).

Under the same climate, at least eleven physiognomies occur in the Cerrado biome and are distributed throughout the landscape based on geomorphology and soil type. The cycling of nutrients in these communities mainly occurs in the litter, where higher concentrations of nutrients are found in the topsoil (Haridasan, 1998). In rural landscapes there is intense luminosity and the limiting factors are related to shallow soil depth, acidity, the high saturation of aluminum, and a low availability of nutrients, such as nitrogen and phosphorus (Goodland and Ferri, 1979; Sarmiento, 1984). Despite this, grassland environments are highly complex, with many endemic herbaceous and shrub species (Ratter et al., 1996). Therefore, factors that vary according to physiognomies, such as the availability of water, nutrients, and luminosity (Eiten, 1984), directly influence the physiology and ecology of species, which, in turn, have limitations on occupation due to their evolutionary history, specific niches, or the potential for wide distribution (Wright et al., 2001; Hoffmann and Franco, 2003).

There are significant changes in vegetation over short distances in ecotones, which are transition environments between two or more different types of similar vegetation. Ecotones are places where certain species can reach their distribution limits, as they are generally not adapted to survive in adjacent ecosystems. In these transition environments, the magnitude of fluctuation in the limiting factors may be more significant, interfering positively or negatively in the intrinsic processes of the population. This can result in localized processes of vegetation expansion or contraction (Furley and Ratter, 1990).

The transitions between forest and countryside physiognomies in the Cerrado biome are generally

Revista Árvore 2021;45:e4529 
abrupt, as evidenced by the change in tree density, species composition and floristic gradient (Felfili and Silva-Júnior, 1992) in response to nutritional differences and soil moisture content. Due to the proximity between ecosystems, Hopkins (1992) contends there is a possibility that one type of vegetation will advance over another type or the boundary between the two types of vegetation will remain stable. Factors such as climate, hydrology, soil, herbivory, and fire are the main determinants in the location of plant physiognomies (Furley and Ratter, 1990; Hopkins, 1992; Cole, 1992). In areas protected from fires, the gradual expansion of the forest can occur, especially in savanna regions with annual precipitation above $800 \mathrm{~mm}$ (Durigan and Ratter, 2006). It is assumed that the boundaries between physiognomies can change over time (Furley, 1992). This assumption is based on the interdependent relationships between the environment and vegetation, which can influence the climatic and edaphic characteristics of the surrounding environment (Sternberg, 2001).

Thus, long-term monitoring allows us to analyze strategies for reproduction and the occupation of habitats, how to best elaborate management plans, and, above all, to predict the effects of disturbances on the behavior of plant populations. According to Hoffmann (2005), comparative ecological studies between species of the physiognomies involved are necessary to understand the dynamics of ecotonal regions. Few species occur regularly in the Cerrado or in the Mata de Galeria under a restricted sense (Felfili and Silva Júnior, 1992). The species Tachigali rubiginosa (Mart. Ex. Tul.) Oliveira-Filho (Caesalpiniaceae), known as Carvoeiro-da-mata, is fast-growing in the natural areas of Mata de Galeria. It is considered a pioneer species due to its abundance in marginal lands and roadsides (Felfili, 1995; Felfili et al., 1999). The plant blooms from December to April, and the vegetable-type fruits ripen from April to May, which later release seeds that are dispersed by the wind (Felfili et al., 1999).

Field observations carried out on the Água Limpa farm in the Federal District (DF), Brazil, suggest that the Mata de Galeria of the Capetinga stream is advancing over the adjacent vegetation over the years, represented by the physiognomy of Campo Sujo. Geiger et al. (2011) observed a similar process at the limit between Mata de Galeria and
Savana, which burned once in the last 35 years at the Ecological Reserve of the Institute of Geography and Statistics (IBGE) in the DF. Additionally, RodriguesSouza et al. (2015) monitored tree communities in the Savanna, Floresta Seca, and Mata Ciliar gradient for 15 years and noted the expansion of the forest towards the savanna at the Panga Ecological Station in Uberlândia, Minas Gerais.

In this sense, the dynamics of the population of the tree species Tachigali rubiginosa (Mart. Ex. Tul.) Oliveira-Filho as a model species was monitored for eleven years to evaluate the occupation strategy and spatial structure of this species within the ecotone between Mata de Galeria and Campo Sujo, located in the Capetinga stream basin, at Fazenda Água Limpa, DF.

\section{MATERIAL AND METHOD}

\subsection{Study area}

The study was carried out at Fazenda Água Limpa ( $15^{\circ} 56^{\prime}$ 'to $15^{\circ} 59^{\prime} \mathrm{S}$ and $47^{\circ} 55^{\prime}$ 'to $47^{\circ} 58^{\prime} \mathrm{W}$ ), located south of the Federal District (DF). The farm is owned by the University of Brasilia and has an area of approximately 4,000 ha. It is contiguous to the Ecological Reserves of the Botanical Garden and the Brazilian Institute of Geography and Statistics (IBGE), which constitutes the Wild Life Zone of the Environmental Protection Area Cabeça de Veado that has a total protected areas of about 9,000 ha.

According to Köppen-Geiger classification, the region's climate can be characterized as Tropical savanna (Aw), Subtropical humid (Cwa), and Subtropical highland climate $(\mathrm{Cwb})$ that extends over $45 \%, 46 \%$, and $9 \%$ of the territory of the Federal District, respectively. It is characterized by two welldefined seasons: one hot and rainy (from October to April), and the other cold and dry (from May to September). The annual average temperature is $21^{\circ} \mathrm{C}$, with a maximum average of $22^{\circ} \mathrm{C}$ in September and a minimum average of $18{ }^{\circ} \mathrm{C}$ in July, with an average precipitation of 1,500 $\mathrm{mm}$ (INMET, 2019).

In the ecotone between the Mata de Galeria and the Campo Sujo, the study area is located on a concrete cambisol with an average clayey, gravel texture, and on a terrain with a slope of $19 \%$. In the demarcated area, there are humid depressions in the terrain perpendicular to the edge of Mata de Galeria

Revista Árvore 2021;45:e4529 
and another at approximately $45^{\circ}, 50 \mathrm{~m}$ away from the edge of the Forest.

\subsection{History of fires}

The first references to the burning in the Mata de Galeria of the Capetinga stream were from Ratter in 1976, when he visited the Água Limpa farm (Ratter, 1991, unpublished data). According to the author, the burning that occurred in the dry season of 1975 could be evidenced by the carbonization of fallen trunks and branches in the interior of Mata de Galeria. In 1987, a big fire hit the area again, opening several clearings (Felfili and Silva Júnior, 1992). Since then, the area has remained without a record of fires.

\subsection{Sampling method}

The studied area covers where there is evidence of advancement of the Mata de Galeria over the adjacent Campo Sujo. Thus, 31 transects of $5 \mathrm{~m}$ by $100 \mathrm{~m}$ were systematically allocated (Figure 1), perpendicular to the course of the Capetinga stream, covering a strip of vegetation that includes Mata de Galeria to Campo Sujo. Each transect was subdivided into 20 plots of 5 $\mathrm{m}$ by $5 \mathrm{~m}$, corresponding to 620 plots.

The study area covers 1.56 ha, where 88 plots (0.22 ha) were distributed in Mata de Galeria; 62 plots (0.16 ha) in the Mata de Galeria / Campo Sujo ecotone and 470 plots (1.18 ha) in the Campo Sujo. The transition strip from the limit of $5 \mathrm{~m}$ inland from the edge to the Mata de Galeria area and $5 \mathrm{~m}$ from the edge into the Campo Sujo area was called an ecotone.

\subsection{Data collection}

A population survey was carried out in each environment during the dry season in June of 2007 , 2008, 2012, 2014, and 2018. The 620 plots were measured for the height and diameter at breast height (DBH $=1.30 \mathrm{~m}$ from the ground) of individuals considered adult trees $(\mathrm{DBH} \geq 5 \mathrm{~cm})$, and only the height for individuals considered to be young trees (height $>1 \mathrm{~m}$ and $\mathrm{DBH}<5 \mathrm{~cm}$ ) and seedlings (height $\leq 1 \mathrm{~m}$ and $\mathrm{DBH}<5 \mathrm{~cm})$. The height was taken using a graduated ruler $(\mathrm{cm})$, and the circumference was measured with a tape measure $(\mathrm{cm})$; later, to calculate the diameter of the shaft, the circumference in centimeters was divided by the value of $\pi(3.14)$. Each individual was marked with aluminum plates containing an identification number.
The species was identified through consultation with a specialist and compared with exsiccates from the herbarium of the University of Brasilia (UnB). The specimens were then deposited in the mentioned herbarium.

\subsection{Data analysis}

The information in the field spreadsheet was reproduced in Excel spreadsheets. The spatial distribution was investigated between all of the years from 2007 up to 2018. For this purpose, according to the mean and variance values for each year, the dispersion coefficient (CD) and the Green index (IG) were estimated. (Brower and Zar, 1984; Ludwig and Reynolds, 1988). When the CD has a ratio between the values of variance and means less than one, the sample has a uniform type classification. If the ratio is equal to one, the sample has a random classification, and when greater than one, the classification is aggregated or grouped (Brower and Zar, 1984). For the IG, values less than zero mean random distribution, while values equal to zero mean uniform distribution and greater than zero signify an aggregate distribution (Ludwing and Reynolds, 1988).

Mortality, recruitment, and population density of $T$. rubiginosa were calculated from annual surveys. The calculation was based on the number of individuals at the beginning of the sampling (No), the total number of new and dead individuals each year, and the environment (Mata de Galeria / Ecotone / Campo Sujo).

The diameter and height data collected in 2007 , 2008, 2012, 2014, and 2018 were used to characterize the population structure. Frequency histograms were constructed based on the intervals of diameter classes for individuals considered to be adults and the intervals of height class for individuals considered as adults, young trees, and seedlings. The formula defined the class intervals:

\section{$\mathrm{A} / \mathrm{K}$}

where: A represents the amplitude of the values (for height and diameter), and $\mathrm{K}$ is defined by the Sturges algorithm, as shown in the formula below:

$$
\mathrm{K}=1+3.3 \times \log \mathrm{N}
$$

where: $\mathrm{N}$ is the number of individuals sampled (Gerardi and Silva, 1981). 
Table 1 - Demographic parameters of the population of Tachigali rubiginosa in Mata de Galeria / Ecotone / Campo Sujo at Fazenda Água Limpa, Federal District, over the years of sampling. N - Number and Density (ind / ha); NR - Number of individuals recruited; TR\% - Recruitment rate; NM - Number of individuals killed; TM - Mortality rate; Var. - Variance; CD - Dispersion Coefficient; IG - Green Index. 2007 to 2018.

Tabela 1 - Parâmetros demográficos da população de Tachigali rubiginosa na Mata de Galeria/ Ecótono/ Campo Sujo na Fazenda Água Limpa, Distrito Federal, ao longo dos anos de amostragem. N - Número e Densidade (ind/ha); NR - Número de indivíduos recrutados; TR\% - Taxa de recrutamento; NM - Número de individuos mortos; TM - Taxa de mortalidade; Var. - Variância; CD - Coeficiente de Dispersão; IG - Índice de Green. 2007 a 2018.

\begin{tabular}{lccccccccc}
\hline Year & N (ind/ha) & NR & TR\% & NM & TM\% & Average & Var & CD & IG \\
\hline 2007 & $280(179,5)$ & - & - & - & - & 0,4 & 2,0 & 4,5 \\
2008 & $288(184,6)$ & 12 & 4,3 & 4 & 1,4 & 0,5 & 2,1 \\
2012 & $320(205,1)$ & 65 & 23,2 & 33 & 11,8 & 0,5 & 2,2 \\
2014 & $395(253,2)$ & 94 & 33,6 & 19 & 6,8 & 0,6 & 3,2 & 8,5 \\
2018 & $410(262,8)$ & 86 & 30,7 & 71 & 25,4 & 1,0 & 4,3 & 4,1 \\
\hline
\end{tabular}

\section{RESULTS}

In 11 years, the total of T. rubiginosa increased from 179.5 ind / ha in 2007 to 262.8 ind / ha in 2018. That is an absolute increase of 130 individuals in the area, totaling 410 individuals. The recruits totaled 257 individuals and 127 dead. In 2018, the recruitment rate was $30.7 \%$ whereas the mortality rate was $25.3 \%$, the latter of which is higher than the previous years evaluated. The number of individuals killed rose from 19 in the inventory carried out in 2014 to 71 in 2018. Of those 71 , one individual belonged to the adult category $(1.4 \%), 11$ were young trees $(15.5 \%)$ and 59 were seedlings $(83,1 \%)$ (Table 1$)$.

In 2007, out of the 280 individuals in 1.56 ha, 96 individuals were in Mata de Galeria (0.22 ha), 103 in the ecotone (0.16 ha), and 81 in Campo Sujo (1.18 ha). In 2018, this proportion changed when the number of individuals decreased in Mata de Galeria by $20 \%$ ( 83 individuals), increasing in the ecotone by
$32.9 \%$ (135) and, mainly, in Campo Sujo, by $47.3 \%$ (194) (Figure 1).

In 2018, the population dispersion coefficient was 4.10, which indicated a grouped distribution. The Green index was 15.84, confirming the referred distribution. In addition, it was observed that for all of the years evaluated, the population presented itself in a grouped distribution (Table 1).

The number and percentage of individuals over the years distributed in the categories of adult, young tree, and seedlings (Table 2) indicate that, of the 410 individuals registered in 2018, 126 (30.7\%) were classified as adults, $161(39.2 \%)$ as young trees and $123(30.0 \%)$ as seedlings. The number of individuals in the seedling category more than doubled, increasing from 58 in 2007 to 123 in 2018 . However, over the evaluated period, there was a decrease from 152 seedlings in 2014 to 123 in 2018.

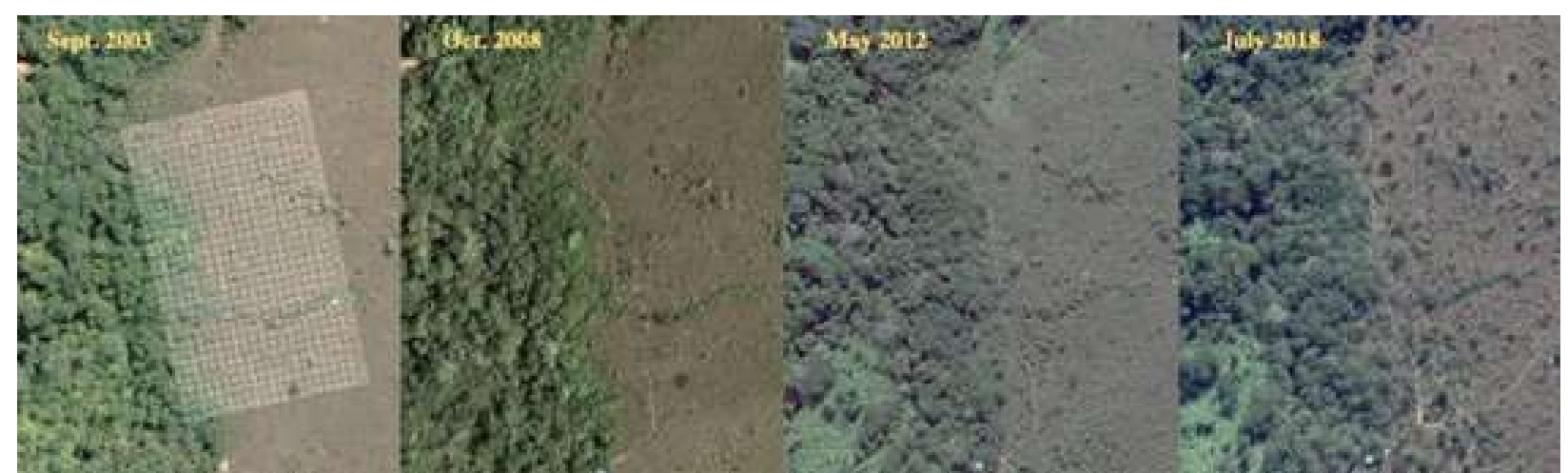

Figure 1 - Time variation - 2003 (four years before the beginning of the experiment) with emphasis on the arrangement of the 31 transects of $5 \mathrm{~m}$ by $100 \mathrm{~m} ; 2008$; (one year after the beginning of the experiment); 2012 (five years after) and 2018 (11 years after) observed in the study area, Mata de Galeria / Ecotone / Campo Sujo at Fazenda Água Limpa, Federal District. Images: Google Earth Pro.

Figura 1 - Variação temporal - 2003 (quatro anos antes do início do experimento) com destaque da disposição dos 31 transectos de 5 m por $100 \mathrm{~m}$; 2008; (um ano após início do experimento); 2012 (cinco anos após) e 2018 (11 anos após) - observado na área de estudo, Mata de Galeria/ Ecótono/ Campo Sujo na Fazenda Água Limpa, Distrito Federal. Imagens: Google Earth Pro. 
Table 2 - Number of individuals and percentage of adults, young trees, and seedlings of Tachigali rubiginosa in Mata de Galeria / Ecotone / Campo Sujo at Fazenda Água Limpa, Federal District between 2007 and 2018.

Tabela 2 - Número de indivíduos e porcentagem de adultos, arvoretas e mudas de Tachigali rubiginosa na Mata de Galerial Ecótono/ Campo Sujo da Fazenda Água Limpa, Distrito Federal entre 2007 e 2018.

\begin{tabular}{ccccr}
\hline Year & Adults & Young trees & Seedlings & Total \\
\hline 2007 & $80(28,6 \%)$ & $142(71,0 \%)$ & $58(20,7 \%)$ & 280 \\
2008 & $94(32,6 \%)$ & $134(69,1 \%)$ & $60(20,8 \%)$ & 288 \\
2012 & $107(33,7 \%)$ & $125(39,0 \%)$ & $88(27,5 \%)$ & 320 \\
2014 & $120(30,4 \%)$ & $123(31,1 \%)$ & $152(38,5 \%)$ & 395 \\
2018 & $126(30,7 \%)$ & $161(39,3 \%)$ & $123(30,0 \%)$ & 410 \\
\hline
\end{tabular}

In general, when the percentage of individuals in the categories concerning the total were observed in 2007 , trees dominated with $71 \%$ of the individuals, followed by adults (28.5\%) and seedlings (20.7\%). By 2018, although the groves still represented the majority of individuals $(39.2 \%)$, there was a balance between the categories (Table 2).
The population structure showed an inverted "J" distribution, both for diameter and height, with many individuals in the first size classes and a decrease in the last (Figures 2 and 3).

There was an increase in the number of individuals in the second $(8.9-12.8 \mathrm{~cm})$ and third $(12.8-16.6 \mathrm{~cm})$ diameter classes (Figure 2) over the course of the eleven years of study. Additionally, the most significant number of individuals in the first class $(5.0-8.9 \mathrm{~cm})$ was observed in comparison with the others over the years, except in 2018, when the number of individuals observed in the first class was practically equivalent to those observed in the second class $(8.9-12.7 \mathrm{~cm})$.

The population structure of T. rubiginosa for the height variable showed that the first class (0.1-1.5 $\mathrm{cm})$ in 2007 had 75 individuals and, after 11 years, that number increased to 155 individuals. For all the

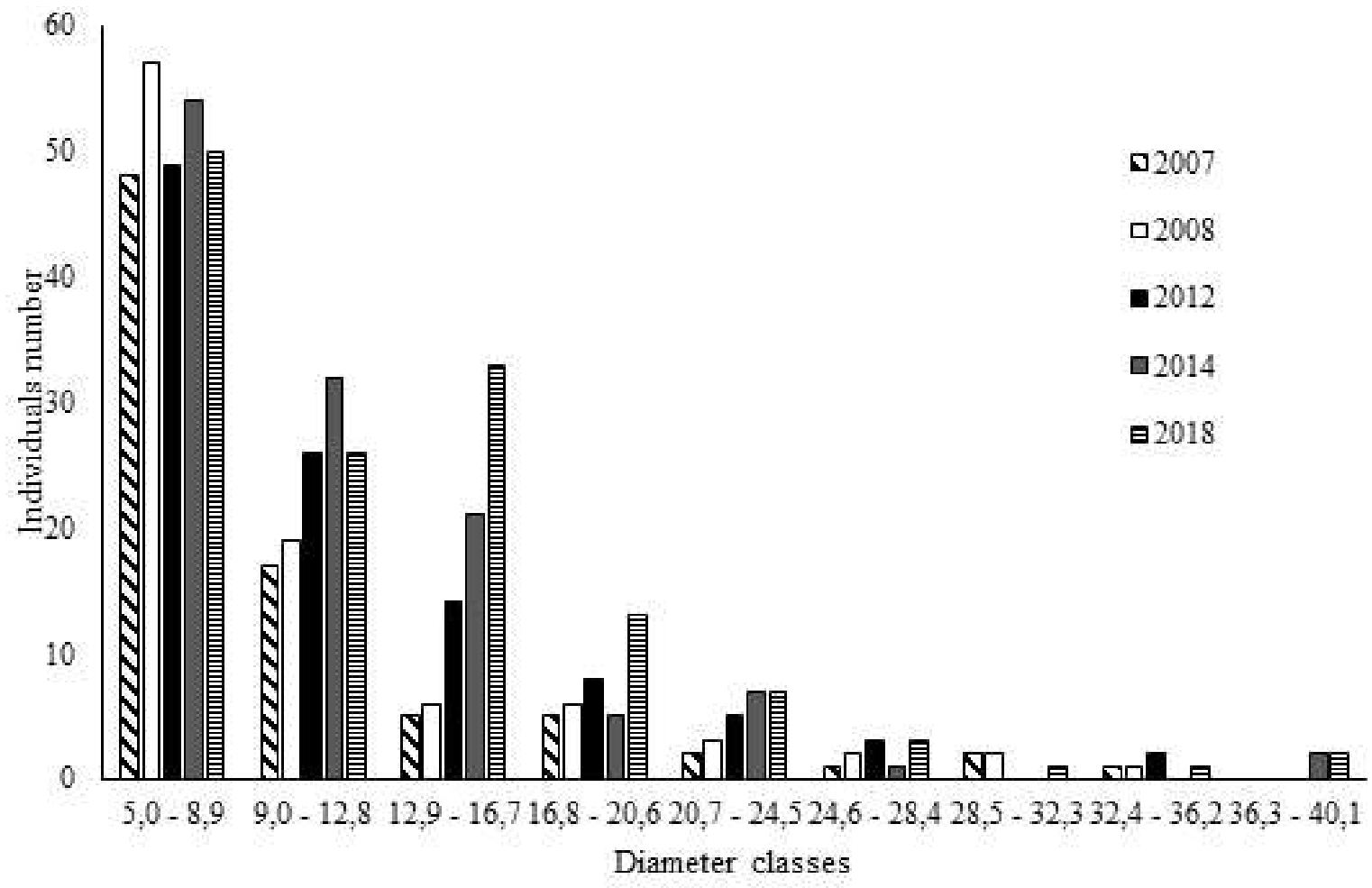

Figure 2 - Number of individuals distributed in diameter classes of the population of Tachigali rubiginosa in the Ecotone / Mata de Galeria / Campo Sujo at Fazenda Água Limpa, Federal District, years 2007, 2008, 2012, 2014, and 2018.

Figura 2 - Número de indivíduos distribuídos em classes de diâmetro da população de Tachigali rubiginosa no Ecótono / Mata de Galeria / Campo Sujo na Fazenda Agua Limpa, Distrito Federal, anos de 2007, 2008 2012, 2014 e 2018.

Revista Árvore 2021;45:e4529 


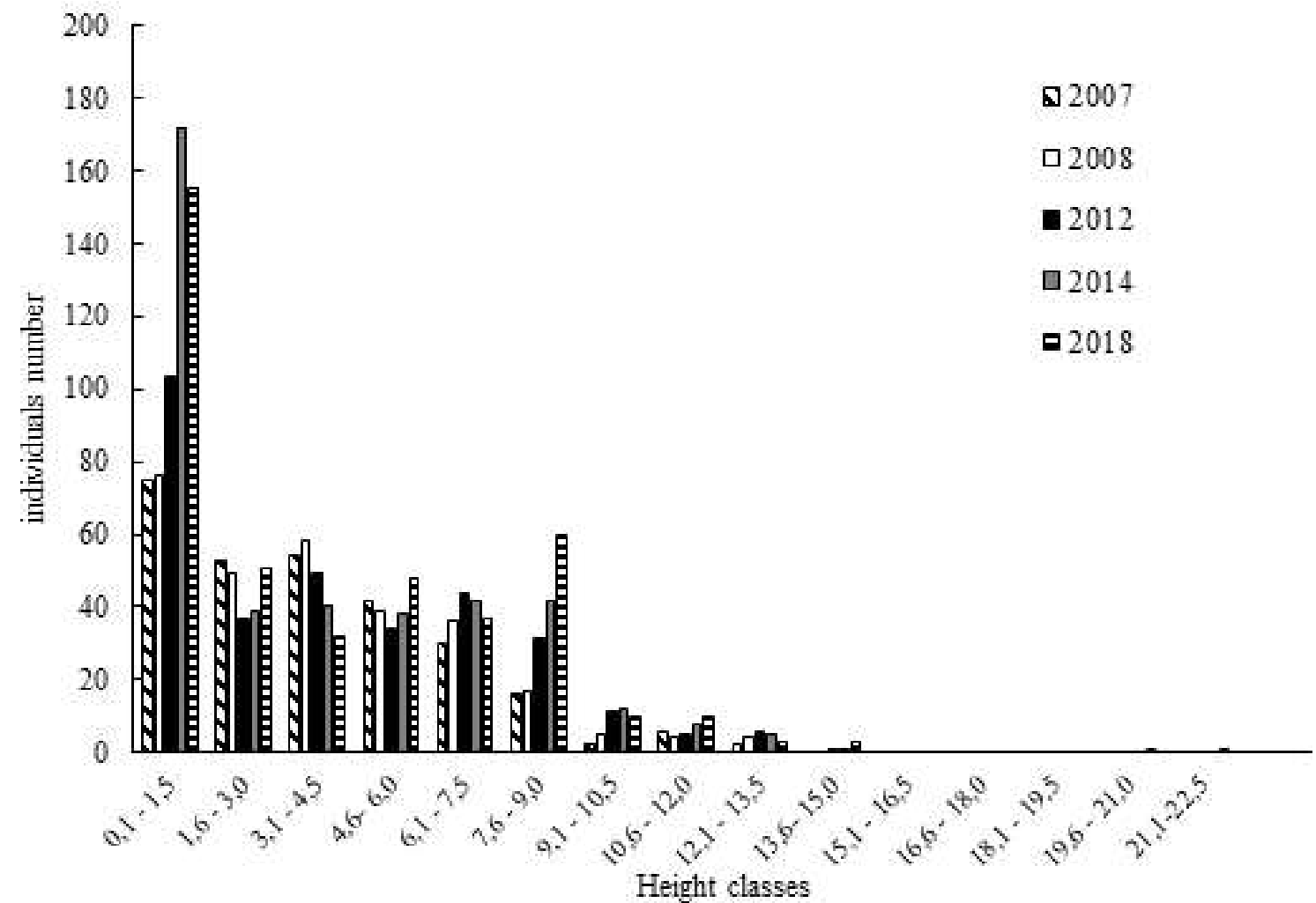

Figure 3 - Number of individuals distributed in height classes of the population of Tachigali rubiginosa in the Ecotone Mata de Galeria / Campo Sujo at Fazenda Água Limpa, Federal District, 2007, 2008, 2012, 2014, and 2018.

Figura 3 - Número de indivíduos distribuídos em classes de altura da população de Tachigali rubiginosa no Ecótono Mata de Galerial Campo Sujo na Fazenda Água Limpa, Distrito Federal, anos de 2007, 2008, 2012, 2014 e 2018.

years studied, this class was represented by the most significant number of individuals.

\section{DISCUSSION}

Natural populations are dynamic, with mortality and birth rates constantly changing due to intra and inter-specific interactions with the environment (Ricklefs, 1993). The inverted "J" pattern observed for the analyzed population was also obtained in studies by Aquino et al. (2007), Carvalho et al. (2009), Arantes and Schiavini (2011), and Cappelatti and Schmitt (2015), who attribute the pattern to population's selfregenerative capacity. Regenerative capacity refers to greater recruitment and lower mortality, which allows them to be in dynamic balance. The changes observed in the studied population of T. rubiginosa showed that the recruitment rate was always lower than mortality in all the sampled periods, pointing to population growth.
The higher mortality rate observed in the smaller diameter classes may be related to competition for space and resources among smaller individuals since they exhibit greater density and a grouped spatial distribution (Baker et al., 2003). In addition to these, Saboya and Borghetti (2012) and Palma and Laurance (2015) point to water stress as one of the leading causes of seedling mortality in the field.

Regarding the physiognomies analyzed, the results pointed to a significant increase in the number of regenerants in Campo Sujo. The species T. rubiginosa seems to present phenotypic plasticity, which allows the occurrence of individuals along environmental gradients (Felfili, 1995). Studies corroborated this behavior by Felfili et al. (1999), who evaluated the behavior of T. rubiginosa seedlings at different levels of shade in a nursery, finding greater production of dry matter in seedlings that were under the condition of less shade ( $50 \%$ of shade). This confirms the 
phenotypic plasticity of this species, depending on the level of shading. Additionally, a study by Felfili (1995) highlighted that the preferred habitat of this species is at the edges of the forests, where periodic disturbances occur with intermediate solar radiation.

The physiognomies of Campo Sujo are formed by sparsely-developed shrubs and sub-shrubs interspersed with grasses (Ribeiro and Walter, 2008). However, as Durigan and Ratter (2006) stated, if this physiognomy is protected from fire, as it has been happening for 32 years in the present study area, forest trees species from neighboring areas can expand in density and grow in size. This fact can be corroborated by fire suppression experiments in savannas (Bond et al. 2005; Geiger et al. 2011; Scott et al. 2012) that provide evidence suggesting more open vegetation types can be progressively replaced by forests, especially in places with more than 800 $\mathrm{mm}$ of average annual precipitation (Durigan and Ratter, 2006).

Thus, long intervals without fire can allow forest tree species to enter savanna environments which promotes changes in flora and vegetation structure. Levine et al. (2006) and Vitousek (2004) pointed out that changes in flora and structure can affect both the availability and the efficiency in the use of limiting resources available to plants, which determine the changes in soil conditions and even in the stimulation of symbiotic interactions. Reinforcing this hypothesis, Dahlgren et al. (2003) and Silva et al. (2013) observed the expansion of trees in pastures and dystrophic savannas that altered the patterns of nutrient cycling and accumulation. This expansion triggering biogeochemical feedback cycles that increased soil fertility and induced changes in the ecosystem's floristic structure and composition. In addition to Silva and Anand (2011), these authors stated that such situations indicate the establishment of individuals of some species can trigger forest expansion, despite the apparent abiotic limitation of the environment.

In this sense, in the study area, it was found that in addition to T. rubiginosa, a tree species typical of Mata de Galeria, such as the late secondary Cabralea canjerana (Vell.) Mart. (Meliaceae) and the initial secondary Maprounea guianensis (Aubl) (Euphorbiaceae), were also present in the ecotone and Campo Sujo areas. Arantes et al. (2014) observed forest species expanding into areas of the
Cerrado sensu stricto influenced by environmental changes promoted by the savanna species Bowdichia virgilioides Kunth. (Fabaceae). According to Peroni and Hernández (2011), pioneer forest species have accelerated growth and provided shaded environments that allow other species to establish themselves.

Another aspect that may offer ecological advantages to the genus Tachigali is in the fact that it contains nodulation in the roots, resulting in symbiotic bacteria fixing atmospheric nitrogen (Faria et al., 1989), which may allow better competitive capacity due to the greater nutrient assimilation.

The concentration of individuals in the firstsize classes and the aggregate distribution can also be related to high seed production and anemochoric dispersion of $T$. rubiginosa. Souza-Pietro et al. (2014) evaluated the seed rain in forest remnants in Mato Grosso (MT) and recorded a density of 17 seeds $/ \mathrm{m}^{2}$ only in October. The authors considered $T$. rubiginosa to be one of the most prevalent seeds in the evaluated area, with an occurrence of $80 \%$. Salles and Schiavini (2007) considered that the high investment of species in reproduction could be an evolutionary strategy since few individuals escape the processes of predation and competition and manage to reach adulthood. Therefore, key ecological characteristics of $T$. rubiginosa can contribute to offering a high capacity of the species to thrive in marginal and transition environments, as observed in the limits of Mata de Galeria / Campo Sujo in the Capetinga stream basin, Fazenda Água Limpa. The observations made place an emphasis on the characteristics of high annual seed production, the plasticity in the face of variations in light radiation, and the association with nitrifying bacteria.

\section{CONCLUSIONS}

The increase in Tachigali rubiginosa indicates that this species expanding from the forest environment into the Ecotone area (Mata de Galeria / Campo Sujo) and towards the Campo Sujo of Fazenda Água Limpa.

The increase in the number of young Tachigali rubiginosa individuals in the evaluated period indicates the persistence of this forest tree species in the Ecotone (Mata de Galeria / Campo Sujo) and Campo Sujo over time, if the area remains free of fire.

Revista Árvore 2021;45:e4529 
Understanding how certain environments permit the expansion of forest tree species, and how this establishment changes local environmental conditions and facilitates succession helps to explain the occurrence of some forest species in open field ecosystems. Such a pattern is a fundamental starting point to elucidate longer-term forest expansion.

\section{AUTHOR CONTRIBUTIONS}

The authors give a special thanks to Newton Rodrigues, Roberto Ogata, Wanderlice Santos Soares, Daiane Gonçalves, Simone Santos and Júnia Pires for their help in collecting field data.

\section{REFERENCES}

Aquino FG, Walter BMT, Ribeiro JF. Dinâmica de populações de espécies lenhosas de Cerrado, Balsas, Maranhão. Revista Árvore. 2007;31(5):793-803. doi $10.1590 / \mathrm{S} 0100-67622007000500003$

Arantes CS, Schiavini I. Estrutura e dinâmica da população de Amaioua guianensis AUBL. (Rubiaceae) em fragmento urbano de Floresta Estacional Semidecidual - Uberlândia, Minas Gerais Bioscience Journal. 2011;27(2):312-321.

Arantes CS, Vale VS, Oliveira AP, Prado-Júnior JA, Lopes SF, Schiavini I. Forest species colonizing cerrado open areas: distance and area effects on the nucleation process. Brazilian Journal of Botany. 2014;37(2)143-150. doi: 10.1007/s40415-014-00518

Baker TR, Burslem DFRP, Swaine MD. Associations between tree growth, soil fertility and water availability at local and regional scale in Ghanaian tropical rain forest. Journal of Tropical Ecology. 2003;19(2)109-125. doi: 10.1017/ S0266467403003146

Bond WJ, Woodward FI, Midgley GF. The global distribution of ecosystems in a world without fire. New Phytologist. 2005;165(2):525-38. doi: 10.1111/j.1469-8137.2004.01252.x.

Brower JE, Zar JH. Field \& laboratory methods for general ecology. Boston: W.C. Brown editors, 1984.

Cappelatti L, Schmitt JL. Spatial distribution and population structure of Palms (Arecaceae) in a forest fragment of lowland Dense Humid Forest in South Brazil. Ciência Florestal. 2015;25(4):817-825. doi:10.5902/1980509820577

Carvalho LCS, Gonzaga APD, Machado ELM, Souza H, Botrel RT, Silva VF, Rodrigues LA, Oliveira-Filho AT. Estrutura temporal de sete populações em três fragmentos florestais no Alto Rio Grande, Minas Gerais. Cerne. 2009;15(1):58-66.

Cole MM. Influence of physical factors on the nature and dynamics of forest-savanna boundaries. In: PA Furley, J Proctor, JA Ratter, editors. Nature and dynamics of forest-savanna boundaries. London: Chapman and Hall, 1992.

Dahlgren RA, Horwath WR, Tate KW, Camping TJ. Blue oak enhance soil quality in California oak woodlands. California Agriculture. 2003;57(2):4247.

Durigan G, Ratter JA. Successional changes in cerrado and cerrado/forest ecotonal vegetation in western São Paulo State, Brazil, 1962-2000. Edinburgh Journal of Botany. 2006;63(01):119-130. doi: $10.1017 / \mathrm{S} 0960428606000357$

Eiten G. Vegetação do Cerrado. In: Cerrado: caracterização ocupação e perspectiva. MN Pinto, editor. Brasília, DF: SEMATEC/UnB; 1984.

Faria SM, Lewis GP, Sprent JI, Sutherland JM. Occurrence of nodulation in the Leguminosae. New Phytologist. 1989;111:607-619. doi: 10.1111/j.1469. 8137.1989.tb02354.x

Felfili JM. Diversity, structure, and dynamics of a Gallery Forest in central Brazil. Vegetatio. 1995;117:1-15. doi: 10.1007/BF00033255

Felfili JM, Hilgbert LF, Franco AC, Silva JCS, Rezende AV, Nogueira MVP. Comportamento de plântulas de Sclerolobium paniculatum Vog. var. rubiginosum (Tul.) Benth. sob diferentes níveis de sombreamento, em viveiro. Revista Brasileira de Botânica. 1999; 22(2):297-301. doi:10.1590/S010084041999000500011

Felfili JM, Silva-Júnior MC. Floristic composition, phytosociology and comparison of cerrado and gallery forests at Fazenda Água Limpa, Federal District, Brazil. In: Furley PA, Proctor J, Ratter JA, editors. Nature and dynamics of forest-Savanna 
boundaries. London: Chapman and Hall; 1992.

Felfili JM, Silva-Júnior MC, Filgueiras TS, Nogueira PE. Comparison of Cerrado (sensu stricto) vegetation in central Brazil. Ciência e Cultura. 1998;50(4):237243.

Furley PA. Edaphic changes at the forest-savanna boundary with particular reference to the neotropics. In: Furley PA, Proctor J, Ratter JA, editors. Nature and dynamics of forest-savanna boundaries. London: Chapman and Hall; 1992.

Furley PA, Ratter JA. Pedological and botanical variations across the Forest-Savanna transition on Maracá Island. The Geographical Journal. 1990;156(3):251-266. doi: 10.2307/635527

Geiger EL, Gotsch SG, Damasco G, Haridasan M, Franco AC, Hoffmann WA. Distinct roles of savanna and forest tree species in regeneration under fire suppression in a Brazilian savanna. Journal of Vegetation Science. 2011;22(2):312-321. doi: 10.1111/j.1654-1103.2011.01252.x

Gerardi LHO, Silva BCN. Quantificação em Geografia. 1a. ed. São Paulo, SP: Editora Difel, 1981

Goodland R, Ferri MG. Ecologia do Cerrado. São Paulo, SP: EDUSP/Livraria Itatiaia Editora Ltda, 1979.

Haridasan M. Solos de mata de galeria e nutrição mineral de espécies arbóreas em condições naturais. In: Ribeiro JF, editor. Cerrado: Matas de Galeria. Planaltina, DF: Embrapa-CPAC; 1998. p.19-28.

Hoffmann WA. Ecologia comparativa de espécies lenhosas de cerrado e de mata. In: Scariot A, SousaSilva JC, Felfili JM, editores. Cerrado: Ecologia, Biodiversidade e Conservação. Brasília, DF: Ministério do Meio Ambiente; 2005. p.157-165.

Hoffmann WA, Franco AC. Comparative growth analysis of tropical forest and savanna woody plants using phylogenetically-independent contrasts. Journal Ecology. 2003;91:475-484. doi: 10.1046/j.1365-2745.2003.00777.x

Hopkins B. Ecological processes at the forest-savanna boundary. In: Furley PA, Proctor J, Ratter JA, editors. Nature and dynamics of forest-savanna boundaries. London: Chapman \& Hall; 1992. p.21-30.
Instituto Nacional de Meteorologia - INMET. Disponível em: <http://www.inmet.gov.br/portal/ > . Acesso em: 10/12/2019.

Kozlowski TT, Kramer PJ, Pallardy SG. The physiological ecology of woody plants. San Diego: Academic Press; 1991.

Levine J, Pachepsky E, Kendall B, Yelenik S, Lambers J. Plant-soil feedbacks and invasive spread. Ecology Letters. 2006;9(9):1005-1014. doi: 10.1111/j.1461-0248.2006.00949.x.

Ludwig JA, Reynolds JF. Statistical ecology: A primer on methods and computing. New York: John Wiley; 1988.

Palma AC, Laurance SGW. A review of the use of direct seeding and seedling plantings in restoration: what do we know and where should we go? Applied Vegetation Science. 2015;18(4):561-568. doi: 10.1111 /avsc. 12173

Peroni N, Hernández MIM. Ecologia de populações e comunidades vegetais. Florianópolis, $\mathrm{SC}$ : $\mathrm{CCB} /$ EAD/UFSC; 2011.

Ratter JA, Bridgewater S, Atkinson R, Ribeiro JF. Analysis of the floristic composition of the brazilian cerrado vegetation II: Comparison of the woody vegetation of 98 areas. Edinburgh Journal of Botany. 1996;53(2):153-180.

Reatto A, Spera ST, Correia JR, Martins ES, Milhomen A. Solos de ocorrência em duas áreas sob Matas de Galeria no Distrito Federal: aspectos pedológicos, uma abordagem química e físicohídrica. In: Ribeiro JF, Fonseca CEL, Sousa-Silva JC, editores. Cerrado: caracterização e recuperação de Matas de Galeria. Planaltina, DF: Embrapa Cerrados, 2001. p.115-140.

Ribeiro JF, Walter BMT. As principais fitofisionomias do bioma Cerrado. In: Sano SM, Almeida SP, Ribeiro JF, editores. Cerrado: ecologia e flora. Planaltina, DF: Embrapa Cerrados; 2008. p.151-212.

Ricklefs RE. A economia da natureza. Rio de Janeiro, RJ: Guanabara Koogan; 1993.

Ricklefs RE, Schluter D. Species diversity: regional and historical influences. In: Ricklefs RE, Schluter 
D, editors. Ecological Communities: Historical and Geographical Perspectives. Chicago: University of Chicago Press;1993. p.350-363.

Rodrigues-Souza J, Prado-Júnior JA, Vale VS, Schiavini I, Oliveira AP, Arantes CS. Secondary forest expansion over a savanna domain at an ecological reserve in the Southeastern Brazil after 15 years of monitoring. Brazilian Journal of Botany. 2015;38(2):311-322. doi: 10.1007/s40415-0150146-x

Saboya P, Borghetti F. Germination, initial growth, and biomass allocation in three native Cerrado species. Brazilian Journal of Botany. 2012;35(2):129135. doi: 10.1590/S0100-84042012000200002.

Salles JC, Schiavini I. Estrutura e composição do estrato de regeneração em um fragmento florestal urbano: implicações para a dinâmica e a conservação da comunidade arbórea. Acta Botanica Brasilica. 2007;21(1)223-233. doi: 10.1590/S010233062007000100021

Sarmiento G. The ecology of neotropical savannas. Cambridge: Harvard University Press; 1984.

Scott K, Setterfield SA, Douglas MM, Parr CL, Schatz J, Andersen NA. Does long-term fire exclusion in an Australian tropical savanna result in a biome shift? A test using the reintroduction of fire. Austral Ecology. 2012;37(6):693-711. doi: 10.1111/j.1442-9993.2012.02379.x

Silva LCR, Anand M. Mechanisms of Araucaria (Atlantic) forest expansion into Southern Brazilian Grasslands. Ecosystems. 2011;(14):1354-1371. doi: 10.1007/s10021-011-9486-y

Silva LCR, Hoffmann WA, Rossatto DR, Haridasan M, Franco AC, Horwath WR. Can savannas become forests? A coupled analysis of nutrient stocks and fire thresholds in central Brazil. Plant and Soil. 2013;373:829-842. doi: 10.1007/s11104-013-1822-x

Souza-Pietro W, Silva NM, Campos EP. Chuva de sementes em remanescentes florestais de Campo Verde, MT. Revista Árvore. 2014;38(4):1-10. doi: $10.1590 / \mathrm{S} 0100-67622014000400012$

Sternberg LSL. Savanna-forest hysteresis in the tropics. Global Ecology and Biogeography. 2001;10(4):369-378.

Vitousek P. Nutrient cycling and limitation: Hawai'i as a model system. Princeton: Princeton University Press; 2004.

Wright IJ, Reich PB, Westoby M. Strategy shifts in leaf physiology, structure and nutrient content between species of high-and low-rainfall and high- and low-nutrient habitats. Functional Ecology. 2001;15(4):423-434. doi: 10.1046/j.02698463.2001.00542.x 